\title{
Determinants of farmers choice of adaptation to climate variability in Dera woreda, south Gondar zone, Ethiopia
}

\author{
Birtukan Atinkut ${ }^{*}$ and Abraham Mebrat
}

\begin{abstract}
Background: Climate variability causes enormous suffering particularly on rural farmers' whose livelihoods depend largely on rain-fed agriculture. Ethiopia in general the Dera woreda in particular is not an exception in this regard. The main purpose of this study was to identify the determinant factors that influence the choice of farmers' adaptation strategies to climate variability from 110 households in Dera woreda, south Gondar zone, Ethiopia. Accordingly, descriptive statistics and Multi-Nominal Logit model (MNL) were employed to analyze the data on household and demographic characteristics and the determinant factors that influences the choice of farmers adaptation, respectively.
\end{abstract}

Results: The results showed that the major climatic related hazards in the study area were flooding (31.8\%), followed by hailstorm (19\%), drought (17.3\%), crop-pest (16.4\%) and livestock epidemic (15.5\%). In order to tackle the effects of climate variability, households in the area pursued crop diversification (38.2 \%), soil and water conservation (31.8\%) and seasonal migration (19\%) as the most dominant and frequent adaptation measures. The MNL model also found that the adaptation measures taken by the households are influenced by some predictor variables such as gender of the household head, age, access to extension services, agro-ecological location, farm size, family size and perception on temperature.

Conclusion: In order to overcome the challenges that the farmers have been facing in employing various adaptation measures in response to climate variability, the government needs to support them in promoting the appropriate adaptation measures suitable in varied agro-ecological zones.

Keywords: Climate variability, Adaptation, Determinants, Multi-nominal logit model

\section{Background}

The effect of climate variability and change is more sever in the developing countries than the developed ones due to high vulnerability and least capacity to cope up to these changes (IPCC 2001; UNFCCC 2007) which is particularly true in the continent of Africa. Africa's high vulnerability to the impacts of climate change and variability is exacerbated by widespread poverty, recurrent droughts and floods, dependence on natural resources and biodiversity, over dependence on rain fed agriculture and

\footnotetext{
*Correspondence: brtknst197@yahoo.com

Faculty of Agriculture and Environmental Science, Department of Disaster Risk Management and Sustainable Development, Bahir Dar University, Bahir Dar, Ethiopia
}

conflicts that have engulfed the continent (Davidson et al. 2003 as cited in Nyong et al. 2007). Agriculture is the basis for the livelihoods of millions of people in Africa. An average of $70 \%$ of the population lives by farming and $40 \%$ of all exports are earned from agricultural products (IPCC 2001). In addition, 10-70 \% of Gross Domestic Product (GDP) in Africa is generated by agriculture (Mendelssohn et al. Mendelsohn et al. 2000). According to reports of the IPCC (2007), the projected yield reduction due to climate change and variability in some poor countries could be as much as $50 \%$ by 2020 (Boko 2007). This is particularly true in Ethiopia, where more than $85 \%$ of its population is dependent on rain-fed agriculture. Since 1980 Ethiopia experienced at least five major

\section{Springer}


droughts caused as a result of decline in rainfall which in turn led to the death of hundreds of thousands of people, which facilitated the country's dependence on food aid. Due to fluctuations in climate, however, Ethiopia became one of the largest receipts of food aid which reached about $20-30 \%$ in the sub-Saharan Africa. Over the last 50 years, Ethiopia experienced both warm and cool years, though the warmest days showed an increment in recent years, particularly by $0.37 \%$ in every ten years (Marye 2011).

Among the Ethiopian regions, however, the Amhara is one of the most vulnerable areas to climate variability and change. The increase temperature along with a decrease in precipitation, have becoming a serious problem in the region that frequently affected the agricultural sector. Crop-pest, livestock epidemic, hailstorm, drought, flood become the most dominant and frequently occurring climate related shocks in the region in general in Dera woreda in particular (Misganaw et al. 2014). In order to tackle or at least to minimize the effects of climate variability on their lives and livelihoods, farmers in the area have been pursuing various adaptation options. However, the choice of particular adaptation measures may be positively or negatively affected by specific variables such as household head's education, access to extension and credit services, climate information, agro-ecology, household income, farming experience, household head age, family size, perception to climate variability, and gender of the household head (Shiferaw and Holden 1998; Belaineh et al. 2004; Nhemachena and Hassan 2007; Aster 2010; Deressa et al. 2009; Arjan et al. 2011; Declan and Lisa 2011; Woldeamlak and Dawit 2011; Gutu et al. 2012; Nabikolo et al. 2012; Badge et al. 2013; Yibekal et al. 2013; Belay 2014; Menberu and Yohannes 2014; Misganaw et al. 2014). However, research on the existing adaptation measures practiced by the farmers' and the determinant factors that affects farmers' choice of adaptation in Dera Woreda is very limited. Understanding the factors associated with adaptation would help policy makers for future intervention to address the challenges of sustainable development to climate variability. Thus, the main purpose of this study was to identify the determinant factors that affect farmers' choice of adaptation in Dera woreda.

\section{Methodology}

\section{Sampling design}

The study is carried out in Dera woreda, located in South Gondar Zone of the Amhara National Regional state of Ethiopia (Fig. 1). The study employed a combination of purposive and random sampling procedures to select the Dera woreda among the districts of the south Gondar

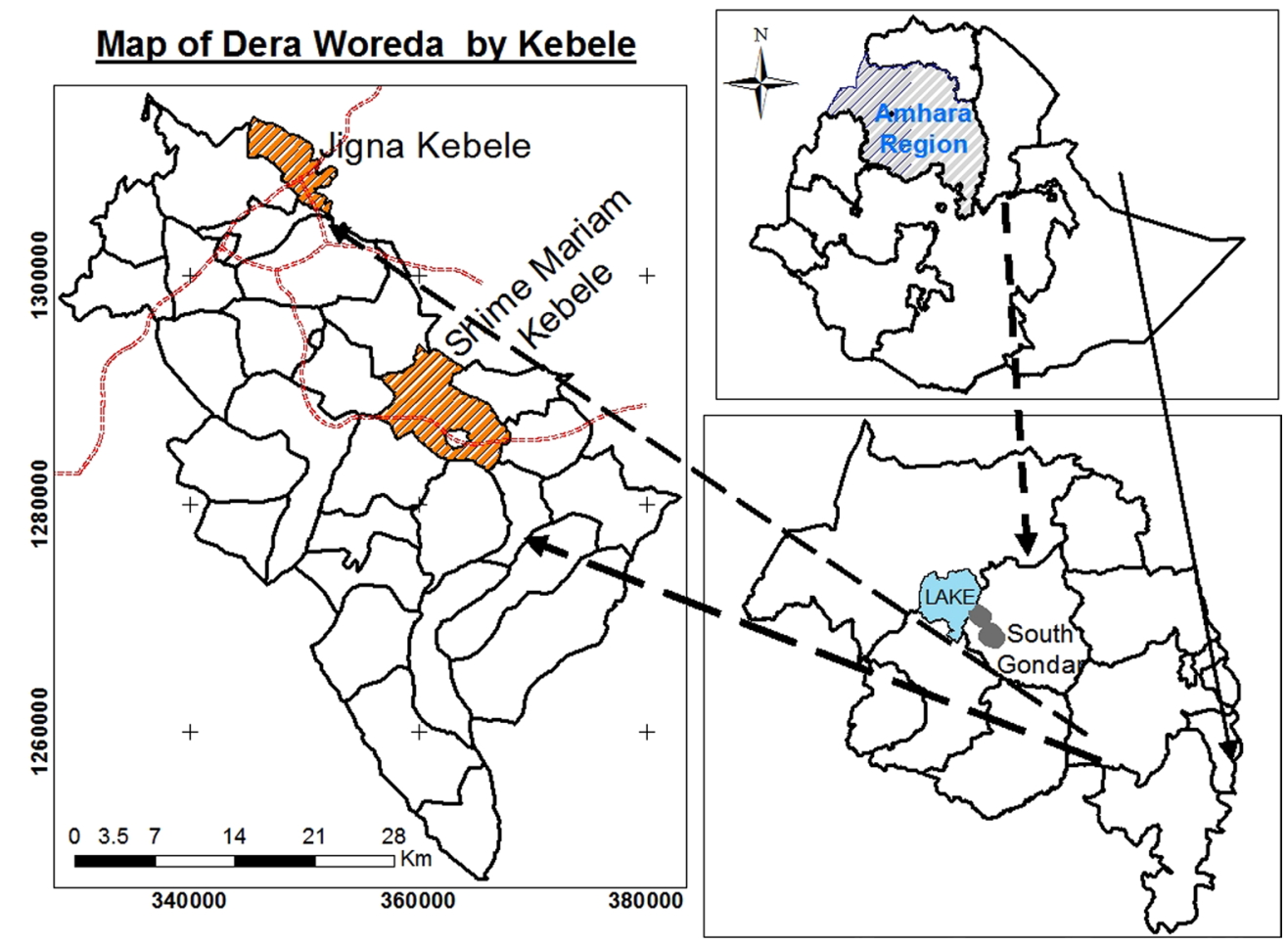

Fig. 1 Location map of the study area 
zone and sample kebeles and households, respectively, during which the former was selected due to its vulnerability to climate variability. Consequently, two kebeles of the district were randomly selected from the woina dega (mid-land) and dega (highland) agro-ecological zones. Afterward, simple random sampling method was used in selecting households' from woina dega and dega in consideration with similar proportions. For this purpose, the formula of Cochran (1977) was used to determine the required sample size at $95 \%$ confidence level, $5 \%$ degree of variability and $7 \%$ level of precision. Using this formula, 110 sample households were selected. However, in order to minimize the risk of non-response or recording error and to make the data more reliable, $5 \%$ contingency was added to the sample size, making the sample size 116 , though only 110 household heads were interviewed by which 6 of them have been dropped due to incomplete or inconsistent data.

The data were collected from both direct and indirect sources. Primary data were collected from key informants, focus group discussion and household survey. Different groups of participants with different socioeconomic groups such as female and male headed households', the elderly and young people, vulnerable social groups including women and wealth groups (poor, middle and better off households'), extension workers, agriculture office workers and local authorities were interviewed. Secondary data were also collected from various government offices in the district, Central Statistical Authority (CSA), reports from agricultural office and published and un-published written sources.

After the data were collected, edited, coded and entered into SPSS 20, it was analyzed using descriptive statistical tools such as mean, percentages, frequencies and standard deviations. Descriptive statistics were used to analyze data on demographic, physical and socio-economic characteristics of households' in the area. Multinominal logit model was also employed to analyze the determinant factors that affect the choice of households' adaptation measures to climate variability. The model is widely used by different researchers (Belaineh et al. 2004; Nhemachena and Hassan 2007; Deressa et al. 2009; Fatuase and Ajibefun 2013; Yibekal et al. 2013; Menberu and Yohannes 2014). The Multinomial logit model is used in dealing with more than two outcomes of the dependent variable. In this study, therefore, the dependent variable, adaptation, has more than two outcomes such as cropdiversification, soil and water conservation and seasonal migration.

\section{Results and discussions}

The majority of female and male headed households' despite differences in sex, age, social roles and agro-ecology perceived climate variability in the study area manifested in terms of erratic rainfall and an increase in temperature for the last couple of years, months and decades. In response to this, the descriptive statistics found that $(89.1 \%)$ of households employed at least one adaptation strategy among others. Based on the importance of each strategy to their livelihood and agricultural activities, crop-diversification (38.2 \%), soiland water conservation (31.8\%) and seasonal migration $(19.1 \%)$ were identified as the major adaptation strategies both in the dega and woina dega agro-ecological zones of the study area.

The explanatory variables that are hypothesized to affect the dependent variable as indicated in Table 1 are agro-ecology, family size, farm size, access to extension service, age, sex of the household head, perception on temperature, farming experience, farmer to farmer extension, water access and climate information while the outcomes of the dependent variables are cropdiversification, soil and water conservation and seasonal migration.

The above explanatory variables were inserted into SPSS version 20 (see Table 2). It was found that the inclusion of all variables did not bring statistically significant relationships, hence some variables such as farming experience, farmer to farmer extension, water access and climate information were rejected in the analysis.

\section{Multi-nominal model results}

The MNL model was run taking "no adaptation" as a base category against other groups to be compared with. In order to see the probability of a particular choice of adaptation for a unit change in the independent variables, the regression coefficients, average marginal effect and their significance levels were used. The likelihood ratio statistics from the MNL model indicated that $\mathrm{x}^{2}$ statistics was highly significant at $\mathrm{p}<0.001$, suggesting that the model has strong explanatory power.

As it is indicated in Table 3, agro ecology woina dega (mid land), age of the household head, family size, farm size, access to extension services and perception to climate variability have significant and positive correlation with crop diversification and the use of SWC while age and farm size have negative but significant association with soil and water conservation and seasonal migration. Agro ecology woina dega(mid land), sex of the household head and access to extension services showed positive and significant relation with seasonal migration. From this one can understand that the choice of a particular measure by a household might be significantly affected by some of the explanatory variables while the other measure might be affected insignificantly with different levels of significance. On the other hand, level of 
Table 1 Variables hypothesized to affect adaptation decisions by farmers' in the study area

\begin{tabular}{|c|c|c|}
\hline Variables & Description and measurement & Variable type \\
\hline AEZWD & $\begin{array}{l}\text { Takes the value of } 0 \text {, if agro-ecology is W/ } \\
\text { Dega, } 1 \text { otherwise }\end{array}$ & Dummy \\
\hline EDUC & $\begin{array}{l}\text { Takes the value of } 0 \text { if cannot read and write } \\
\text { and } 1 \text { otherwise }\end{array}$ & Dummy \\
\hline FAMSIZE & $\begin{array}{l}\text { Number of people in the household, meas- } \\
\text { ured in number }\end{array}$ & Continuous \\
\hline SEX & Takes the value of 0 if male and 1 otherwise & Dummy \\
\hline AGE & Age of household head in years & Continuous \\
\hline FARMINC & Annual income in Birr from on farm activities & Continuous \\
\hline FARMSIZE & $\begin{array}{l}\text { Number of farm sizes owned by a household } \\
\text { in hectares }\end{array}$ & Continuous \\
\hline EXT-SERV & $\begin{array}{l}\text { Takes the value of } 0 \text { if there is access and } 1 \\
\text { otherwise }\end{array}$ & Dummy \\
\hline CREDIT & $\begin{array}{l}\text { Takes the value of } 0 \text { if there is access and } 1 \\
\text { otherwise }\end{array}$ & Dummy \\
\hline CLIMINFO & $\begin{array}{l}\text { Takes the value of } 0 \text { if there is access and } 1 \\
\text { otherwise }\end{array}$ & Dummy \\
\hline FARMEXP & Farming experience of the household head & Continues \\
\hline WATERAC & $\begin{array}{l}\text { Takes the value of } 0 \text { if there is access and } 1 \\
\text { otherwise }\end{array}$ & Continues \\
\hline FAR-FARM & $\begin{array}{l}\text { Takes the value of } 0 \text { if there is access and } 1 \\
\text { otherwise }\end{array}$ & Continues \\
\hline PERC-TE & $\begin{array}{l}\text { Takes the value of } 0 \text { if there is access and } 1 \\
\text { otherwise }\end{array}$ & Continues \\
\hline
\end{tabular}

education of a household head, farming experience, farm income, access to credit and climate information had no statistically significant effect on the selected adaptation measures.

\section{Agro ecology woina dega (AEZW/D)}

Farmers' living in different agro-ecological setting used different adaptation measures in response to climate variability. It has been reported that households' living in areas, where the amount of rainfall is less and high temperature than the average is more likely to employ different measures than households' receiving much rainfall and less temperature (Guto et al. 2012). This implies that rural households' living in the woina dega are more likely to adapt to the changing situations than those in dega due to the existence of high variability in climate compared with dega households. The results of the MNL model, however, shows that farmers' living in woina dega are more likely to use crop-diversification and seasonal migration as the main strategy at $p<0.05$ and $\mathrm{p}<0.01$ respectively relative to the reference category. Living in woina dega can increase the probability of using crop diversification and seasonal migration by 6 and $27 \%$ times greater than those households' living in the dega respectively. This finding is supported by (Belaineh et al. 2004 and Deressa et al. 2008). The difference might be attributed to the difference in soil, climate and other natural resources as well as experiences to climate related stress.

\section{Age of the household head (AGE)}

The results of the MNL model shows that age of the household was found to be positively and significantly correlated with crop-diversification at $\mathrm{p}<0.05$. In this case, a one unit increase in the age of the household increases the probability of using crop diversification by $1.1 \%$. Older farmers' are more likely to involve in

Table 2 Mean comparisons (a one-way ANOVA) of explanatory variables

\begin{tabular}{|c|c|c|c|c|c|c|c|c|c|}
\hline \multirow{2}{*}{$\begin{array}{l}\text { Farm and farm } \\
\text { characteristics }\end{array}$} & \multicolumn{2}{|c|}{ Crop-diversif } & \multicolumn{2}{|l|}{ SWC } & \multicolumn{2}{|c|}{ Migration } & \multicolumn{2}{|c|}{ No-adapt } & \multirow[t]{2}{*}{$p$ value } \\
\hline & Mean & SD & Mean & SD & Mean & SD & Mean & SD & \\
\hline AEZWD & 0.33 & 0.47 & 0.40 & 0.49 & 0.24 & 0.43 & 0.83 & 0.38 & $0.086^{*}$ \\
\hline EDUC & 0.19 & 0.39 & 0.46 & 0.50 & 0.33 & 0.48 & 0.25 & 0.45 & $0.000 * * *$ \\
\hline FAMSIZE & 6.6 & 2.0 & 6.2 & 1.0 & 4.0 & 1.3 & 3.9 & 1.0 & $0.052^{*}$ \\
\hline SEX & 0.21 & 0.41 & 0.03 & 0.16 & 0.05 & 0.218 & 0.17 & 0.38 & $0.000 * * *$ \\
\hline AGE & 55 & 8.8 & 39 & 6.1 & 36 & 10 & 39 & 8.2 & $0.000 * * *$ \\
\hline FARMINC & 1543 & 1168 & 2165 & 1612 & 516 & 604 & 426 & 522 & $0.000^{* * *}$ \\
\hline FARMSIZE & 1.4 & 0.57 & 1.2 & 0.67 & 0.41 & 0.39 & 0.588 & 0.3 & $0.002^{* * *}$ \\
\hline EXT-SERV & 0.31 & 0.46 & 0.63 & 0.49 & 0.43 & 0.50 & 0.83 & 0.38 & 0.181 \\
\hline CREDIT & 0.31 & 0.46 & 0.54 & 0.50 & 0.48 & 0.51 & 0.33 & 0.49 & 0.507 \\
\hline CLIMINFO & 0.52 & 0.50 & 0.60 & 0.49 & 0.71 & 0.46 & 0.67 & 0.49 & $0.000^{* * *}$ \\
\hline FARMEXP & 35.2 & 10.4 & 24 & 12 & 21 & 14 & 16 & 8 & $0.066^{*}$ \\
\hline WATERAC & 1.76 & 0.43 & 1.6 & 0.49 & 1.8 & 0.35 & 1.9 & 0.28 & $0.066^{*}$ \\
\hline FAR-FARM & 0.12 & 0.32 & 0.06 & 0.23 & 0.10 & 0.30 & 0.08 & 0.28 & 0.832 \\
\hline PERC-TE & 1.2 & 0.43 & 1.1 & 0.32 & 1.2 & 0.46 & 1.5 & 0.52 & $0.050^{*}$ \\
\hline
\end{tabular}


Table 3 Parameter estimates of the multinomial logit (MNL) model for adaptation measures to

\begin{tabular}{|c|c|c|c|c|c|c|c|c|c|}
\hline \multicolumn{4}{|c|}{ Crop-diversification } & \multicolumn{3}{|c|}{ Soil and water conservation } & \multicolumn{3}{|c|}{ Seasonal migration } \\
\hline Variables & B & Sig. & $\operatorname{Exp}(B)$ & B & Sig. & $\operatorname{Exp}(B)$ & B & Sig. & $\operatorname{Exp}(B)$ \\
\hline AEWD & 4.242 & $0.035^{* *}$ & 6.531 & 3.111 & 0.113 & 22.446 & 5.621 & $0.005^{* * *}$ & 276.06 \\
\hline AGE & 0.162 & $0.035^{* *}$ & 1.176 & -0.280 & $0.006^{* * *}$ & 0.756 & -0.022 & 0.0759 & 0.852 \\
\hline SEX & 1.139 & 0.577 & 3.124 & 4.314 & $0.055^{*}$ & 0.76 & 5.996 & $0.015^{* *}$ & 401.76 \\
\hline EDUC & 1.391 & 0.516 & 4.020 & 0.786 & 0.681 & 2.196 & 1.300 & 0.485 & 0.096 \\
\hline FAMSI & 0.818 & $0.081^{*}$ & 2.267 & 0.927 & $0.054^{*}$ & 2.526 & 0.109 & 0.810 & 1.115 \\
\hline FARIN & 0.000 & 0.215 & 1.000 & 0.000 & 0.103 & 1.000 & 0.000 & 0.513 & 1.000 \\
\hline FARSI & 4.366 & $0.059^{*}$ & 78.699 & 4.948 & $0.038^{* *}$ & 14.89 & -0.030 & 0.989 & 0.971 \\
\hline EXT & 3.949 & $0.008^{* * *}$ & 51.870 & 2.624 & $0.063^{*}$ & 13.796 & 2.990 & $0.020^{* *}$ & 19.88 \\
\hline CRE-S & 1.655 & 0.268 & 5.233 & -0.882 & 0.537 & 0.414 & -0.018 & 0.989 & 1.982 \\
\hline PER-T & 2.831 & $0.066^{*}$ & 16.963 & 2.640 & $0.067^{*}$ & 14.009 & 0.467 & 0.728 & 1.596 \\
\hline CONS & -22.423 & 0.000 & & -5.823 & 0.147 & & -7.480 & 0.052 & \\
\hline
\end{tabular}

$*^{* *},{ }^{* * *}$ indicates levels of significance at 10,5 and $1 \%$ respectively, dependent variable-adaptation; reference category: no adaptation

crop-diversification than younger ones. The probable reason for the positive association is due to the fact that age may likely endow the farmers' with the requisite experience that will enable them make better assessment of the risks involved in climate change adaptation investment decisions. This argument is in line with Arega (2013) who noted households' who have long experience in farming can predict the trends of crop production better than young households' can. Most of the studies (Deressa et al. 2009; Misganaw et al. 2014) repeatedly argued that an increase in age does mean an increase in farming experience which would increase farmers' indigenous knowledge to respond to the hazards resulted in climate variability.

On the other hand, age of the household head shows negative correlation with soil and water conservation and seasonal migration at $\mathrm{p}<1$ and $\mathrm{p}<10 \%$ which means that a one unit increase in the age of the household decreases the probability of using soil and water conservation and seasonal migration by 0.7 and 0.8 times greater relative to the base category. This implies that older farmers' are less likely to take soil and water conservation and seasonal migration which require more labor. The probability of adapting soil and water conservation and seasonal migration decreases the older a farmer is. Thus, younger households' are active and energized than older households' in the application of soil and water conservation and seasonal migration as a strategy. This finding is in agreement with Madison (2006) who noted that older households' are less likely to use the two adaptation measures compared with younger ones.

\section{Gender of the household head (SEX)}

Gender of the household head is one of the most important variables that significantly affect the farmers' choice of climate variability adaptation options. In the prevalance of climate variability, sex of household head showed positive and significant correlation with soil and water conservation and seasonal migration at $\mathrm{p}<10$ and $\mathrm{p}<5 \%$, respectively. Being male headed households' increase the probability of using soil and water conservation and seasonal migration as an adaptation strategy by 70 and $40 \%$, respectively relative to the reference category. This is because male headed households' have greater preferences to use soil and water conservation as a strategy that require labor, finance and climate information than female headed households'. This is in line with the argument that male headed households' are more likely to get information about new technologies and take risky business than female headed households' (Deressa et al. 2009). Abaje et al. (2013) noted that unlike men, women have limited access to information, land and other resources. On the other hand, seasonal migration as a strategy for female headed households' is less likely used compared with male-headed households.' This argument is in consistent with the study of (Agrawal 1997) asserted that in response to climate risks men are more likely to migrate and leave behind their families in search of secondary employment while women are more likely to stay home and face the situation.

\section{Family size of the household (FAMSI)}

As expected, the MNL model revealed that family size is positively and significantly correlated with the household 
decision to pursue crop-diversification and soil and water conservation at $\mathrm{p}<10 \%$. A one person increase in the family can increase the probability of using the two adaptation measures by 2.2 and $2.5 \%$, respectively. Those households' who have larger family have an opportunity of pursuing various adaptation options in the face of climate variability. Thus, its positive and significant sign clearly shows that the larger the family size, the higher probability to respond to reduce its effects. This argument is repeatedly raised in many literatures (Deressa et al. 2009; Fatuase and Ajibefun 2013; Menberu and Yohannes 2014) who argued that large family is associated with higher labor endowment which would enable a household to accomplish various agricultural tasks especially at peak seasons.

\section{Farm size (FARSI)}

As Table 3 illustrates farm size has appeared to be positively and significantly correlated with crop-diversification and soil and water conservation at $\mathrm{p}<10$ and $\mathrm{p}<5 \%$, respectively relative to the base category. A unit increase in one hectare per household would increase the probability of using both crop diversification and soil and water conservation by 78 and $14 \%$ greater than those households' whose farmland is small. Households' with larger farm sizes are more probably to diversify their crops especially under dry seasons and reduce the negative impacts of climatic variability. This argument is in line with Misganaw et al. (2014) who found the same result.

However, farm size is negatively associated with seasonal migration, which means that a one hectare increase in farm size lowers the probability of using seasonal migration as an adaptation strategy by 0.9 times. When farm size is smaller and smaller, households' opt to use seasonal migration as the major measures to reduce the effects of adverse conditions. Since most of the adaptation measures employed by the rural households' in the woreda are agricultural based, those who do not have land or have small plot, would not have any option rather than migrating to some other places where employment opportunities are available. This result is expected in the sense that the more households' have larger farms, the more they tend to work more intensively on their land instead of going for another alternative to adapt to climate change and variability.

\section{Access to extension service (EXT)}

Among the institutional factors, access to extension contact is one of those significant variables that affect the farmers' choice of adaptation. Results of the MNL models shows that extension contact has positive and significant correlation with the likelihood of choosing the three adaptation measure such as crop-diversification, soil and water conservation and seasonal migration at $\mathrm{p}<0.01$, $\mathrm{p}<0.1$ and $\mathrm{p}<0.05$ respectively. A one unit increase in the extension contact is likely to increase the probability of the farmer to adapt the three adaptation measures by 51,13 and $19 \%$, respectively higher than those households' who do not access extension services. Farmers' who have access to extension services are more likely to be aware of climatic conditions. This result is in line with many researchers (Maddison 2007; Guto et al. 2012; Nhemachena and Hassan 2007) who noticed that farmers' who obtain information through extension workers are more likely informed about the climatic situation and the responses followed.

\section{Perception on temperature (PER-T)}

The results indicated that farmers' perception to climate variability is one of the explanatory variables that affect the choice of farmers' adaptation measures. Perception of households' to the increasing temperature was found to be positively and significantly correlated with the choice of crop-diversification and soil and water conservation at $\mathrm{p}<10 \%$. This study found that farmers' who perceived a change in temperature are more likely to adapt to climate variability by 16 and 14 times greater compared to those who do not perceived a rise in temperature. This is probably because a rise in temperature in a district was more likely to affect farm production and therefore more likely to adapt to reduce its effects. This data is in line with the information collected through key informant interview and focus group discussion that farmers' who did not perceive climate variability did not adapt at all. This possibility is due to the fact that farmers' who perceive the variability in temperature are likely to grow different heat-tolerant crop varieties. Guetibou (2009) found the same result in that farmers' who are aware of changes in climatic conditions have higher chances of taking adaptive measures in response to the observed changes.

\section{Conclusion}

Despite differences in social and gender groups, the majority of rural households' in the study area showed a unified perception on climate variability about the changing temperature and rainfall. Thus, there are no significant differences in perceptions and varying insights among rural households' observing climate variability over the last decades. This might be attributed to an existence of climate related risks such as flooding, hailstorm, crop-pest, livestock epidemic and drought which were identified to be the most frequently occurring climate related risks chosen by the majority of the households' in the area.

Farmers' who could perceive fluctuations in climate pursued at least one measures of adaptation compared 
with those households' who do not perceive variability of climate at all. Thus, crop-diversification, soil and water conservation and seasonal migration were the three most frequently used and important adaptation measures pursued by households' in the study area. However, the choice of adaptation measures chosen by rural households' has been influenced by some explanatory variables. The multinomial logit (MNL) model shows that out of 14 independent variables, 7 were found to be significant at $\mathrm{p}$ value less than 1,5 and $10 \%$. Agro ecology woina dega (mid land), age of the household head, family size, farm size, access to extension services and perception to climate variability have significant and positive correlation with crop diversification and the use of SWC practices while age and farm size have significant and negative association with SWC and seasonal migration. Similarly, sex of the household head, agro ecology woina dega (mid land), age of the household head, family size, farm size, access to extension services and perception to climate variability are significantly and positively associated with soil and water conservation and agro ecology woina dega (mid land), sex of the household head and access to extension services shows positive and significant relation with seasonal migration. Thus, policy formulation on sustainable development should consider the interests of rural households including women. Among others, government policies and strategies should be directed towards fulfilling credit access with low interest rates, provision of adequate extension services with knowledgeable and skilled extension agents who could give climate information on the right time including accessible areas and increasing extension-farmer ratio. Besides, women should be given due emphasis since they are the most vulnerable social groups due to lack of access and control over resources, socio-cultural barriers to plow and access climate information. In general, interventions that enhance income, access to finance, access to farm inputs, access to market should be an integral part of climate change adaptation policies and strategies.

\section{Acknowledgements \\ I would like to thank Dr. Abraham Mebrat, Ato Silesh Teshager and Dr. Arega Bazezew for their un-reserved effort, insightful and constructive comments for making my paper valuable. I am also highly grateful to the National Meteorol- ogy Service Agency of Bahir Dar (NMSA) for providing the necessary data and I also thank my informants in Jigna and Shime kebele, for their hospitality and welcoming approach.}

\section{Source of funding}

The paper did get no financial support from any source of funding.

\section{Competing interests}

The authors declare that they have no competing interests.
Received: 20 August 2015 Accepted: 15 October 2015

Published online: 11 February 2016

\section{References}

Abaje I, Sawa B, Ati A (2014) Climate variability and change, impacts and adaptation strategies in Dutsin-Ma local government area of Katsina State. Bello University, Nigeria

Agrawal A (1997) The role of local institutions in adaptation to climate change. Washington, DC

Arega B (2013) Determinants of rural household food security in droughtprone areas of Ethiopia: case study in Lay Gaint District, Amhara Region. Ph.D. Dissertation, UNISA, Pretoria

Arjan R, Mark B, Minna K, Vincent L, Nico P (2011) Adapting to climate variability: learning from past experience and the role of institutions. Social Development, Papers-SER Regional Workshop

Aster D (2010) Climate change and adaptation in Africa/Ethiopia. International Water Management Institute (IWMI), Addis Ababa

Badge B, Henry N, Jeremias M, Abdu A, Jonathan M, Gemedo D, Assefa T, Kathleen, Kassa H, lan K, Eike L, Cheikh M (2013) Forestry Communications Group. In: Davis CM, Bernart B, Dmitriev A (eds) Farmers'Strategies for Adapting to and Mitigating Climate Variability and Change through Agro-forestry in Ethiopia and Kenya. Oregon State University, Corvallis

Belaineh L, Yared A, Woldeamlak B (2004) Smaller holder farmers' perceptions and adaptation to climate variability and climate change in Doba district, west Hararghe, Ethiopia. Asian J Empir Res 3(3):251-265

Belay T (2014) Climate variability and change in Ethiopia: exploring impacts and adaptation options for cereal production. Ph.D. Thesis, Wageningen University, Netherlands

Boko M (2007) Impacts, adaptation and vulnerability. Cambridge University Press, Cambridge

CSA (2008) Summary and statistical reports of the 2007 population and housing census: population size by age and sex. Bahir Dar

Declan C, Lisa F (2011) Adaptation to climate change in Africa: challenges and opportunities identified from Ethiopia. Glob Environ Chang 21:227-237

Deressa T, Hassen R, Alemu T, Yesuf M, Ringler C (2009) Determinants of farmers' choice of adaptation methods to climate change in the Nile Basin of Ethiopia. J Glob Environ Chang 19:248-255

Dorosh P, Getnet A, de Brauw A, Malek M, Mueller V, Schmidt E, Kibrom T, Thurlow J (2011) The rural-urban transformation in Ethiopia: Ethiopian strategy support program II. Economic Development Research Institute Report, International Food Policy Research Institute, Addis Ababa

Farauta B, Egbule C, Idrisa Y, Agu V (2011) Farmer's perceptions of climate change and adaptation measures in northern Nigeria: an empirical assessment. African Technology Policy Studies Network, Research Paper No 15

Fatuase A, Ajibefun A. (2013). Adaptation to climate change: a case study of rural farming households' in Ekiti State, Nigeria. Impacts World 2013, International Conference on Climate Change Effects, Potsdam

Global Water Initiative (2014) Assessing community vulnerability and adaptive capacity to climate change in Dera and Farta woredas of south Gonder zone, Ethiopia. Assessment report, Addis Ababa

Green W (2000) Econometric analysis, 4th edn. Prentice-Hall, Upper Saddle River Gutu T, Bezabih E, Mengistu K (2012) Econometric analysis of local level perception, adaptation and coping strategies to climate change induced shocks in North Shewa, Ethiopia. Int Res J Agric Sci Soil Sci 2(8):347-363

Halonen M, Nikula J, Pathan A, Rinne P (2009) Ethiopia adapting to climate change, climate screening assessment. Climate Risk Management in Finnish Development Cooperation. Final Report

IPCC (2001) Climate change impacts, adaptation and vulnerability. IPCC working group II, third assessment report. Cambridge University Press, Cambridge

IPCC (2007) Climate change 2007: impacts, adaptation and vulnerability: an assessment report of the intergovernmental panel on climate change. Cambridge University Press, Cambridge

Maddison D (2007) The perception of and adaptation to climate change in Africa. World Bank Policy Research Working Paper 4308, Sustainable Rural and Urban Development Team 
Marye B (2011) Local people's perception on climate change, its impacts and adaptation measures in Simada woreda, south Gondar. M.sc. Thesis, Addis Ababa University, Addis Ababa

Menberu T, Yohannes A (2014) Determinants of the adoption of land management strategies against climate change in Northwest Ethiopia. ERJSSH $1(1)$

Mendelsohn R, Dinar A, Dalfelt A (2000) Climate change impacts on African agriculture. Yale University, New Haven

Misganaw T, Enyew A, Temesgen T (2014) Investigating the determinants of adaptation measures to climate change: a case of Batii district, Amhara region, Ethiopia. Int J Agric Res 9(4):169-186

Nabikolo B, Bashaasha N, Mangheni, Majaliwa J. (2012) Determinant of climate change adaptation among male and female headed households in eastern Uganda. Afr Crop Sci J 20

NAPA (2007) Climate change National Adaptation Program of Action (NAPA) of Ethiopia. Addis Ababa
Nhemachena C, Hassan R (2007) Micro-level analysis of farmers' adaptation to climate change in southern Africa. IFPRI Discussion Paper 00714, IFPRI, Washington

NMSA (National Meteorological Services Agency) (2015) Reports on temperature and rainfall trends. Bahir Dar

Shiferaw B, Holden S (1998) Resource degradation and adoption of land conservation technologies in the Ethiopian highlands: case study in Andit Tid, North Shewa. Agric Econ 27(4):739-752

Woldeamlak B, Dawit A (2011) Agricultural adaptation to climate change: farme responses to experienced climate variability in Ethiopia. http://www.slu.se

World Bank (2006) Ethiopia: managing water resources to maximize sustainable growth. Country Water Resources Assistance Strategy, World Bank, Washington, DC

Yibekal T, Chanyalew A, Getachew E (2014) Understanding the process of adaptation to climate change by small-holder farmers: the case of east Hararghe Zone, Ethiopia. Agric Food Econ Spring Open J: pp 1-13

\section{Submit your manuscript to a SpringerOpen ${ }^{\odot}$ journal and benefit from:}

- Convenient online submission

- Rigorous peer review

- Immediate publication on acceptance

- Open access: articles freely available online

- High visibility within the field

- Retaining the copyright to your article

Submit your next manuscript at $>$ springeropen.com 